University of Nebraska - Lincoln

DigitalCommons@University of Nebraska - Lincoln

Faculty Publications from the Harold W. Manter Laboratory of Parasitology

1997

\title{
Coccidia from Bats (Chiroptera) of the World: A New Eimeria Species in Pipistrellus javanicus from Japan
}

Donald W. Duszynski

University of New Mexico, eimeria@unm.edu

Follow this and additional works at: https://digitalcommons.unl.edu/parasitologyfacpubs

Part of the Parasitology Commons

Duszynski, Donald W., "Coccidia from Bats (Chiroptera) of the World: A New Eimeria Species in Pipistrellus javanicus from Japan" (1997). Faculty Publications from the Harold W. Manter Laboratory of Parasitology. 149.

https://digitalcommons.unl.edu/parasitologyfacpubs/149

This Article is brought to you for free and open access by the Parasitology, Harold W. Manter Laboratory of at DigitalCommons@University of Nebraska - Lincoln. It has been accepted for inclusion in Faculty Publications from the Harold W. Manter Laboratory of Parasitology by an authorized administrator of DigitalCommons@University of Nebraska - Lincoln. 


\title{
COCCIDIA FROM BATS (CHIROPTERA) OF THE WORLD: A NEW EIMERIA SPECIES IN PIPISTRELLUS JAVANICUS FROM JAPAN
}

\author{
Donald W. Duszynski \\ Department of Biology, The University of New Mexico, Albuquerque, New Mexico 87131
}

\begin{abstract}
Fecal samples from 56 Japanese bats representing 6 species in 2 families were examined for coccidian oocysts. Two of the $56(<4 \%)$ were infected with coccidia; however, only 1 animal was infected with sufficient numbers of sporulated oocysts to allow the description of a new species of Eimeria. Sporulated oocysts $(n=150)$ of this new species are subspheroidal, 20.3 $\times 18.1(16-25 \times 14-21) \mu \mathrm{m}$, with ellipsoidal sporocysts $10.6 \times 6.6(8-12 \times 5-8) \mu \mathrm{m}$; this species occurred in 1 of $4(25 \%)$ pipistrelles, Pipistrellus javanicus (Gray, 1838) (Vespertilionidae). Oocysts of another coccidium, also an Eimeria sp., were found in 1 of $3(33 \%)$ horseshoe bats, Rhinolophus ferrumequinum (Schreber, 1774) (Rhinolophidae), but only 2 sporulated oocysts were seen, which is not enough to describe a new species.
\end{abstract}

There are only 14 valid coccidia described from all chiropterans worldwide and all belong to the genus Eimeria (for reviews see Duszynski and Barkley, 1985; Duszynski et al., 1988). While in Japan in 1980, we collected 6 species of bats from 5 localities and examined their feces for coccidian oocysts. Feces of only 2 bats, 1 pipistrelle, Pipistrellus javanicus (Gray, 1838) (Vespertilionidae), and 1 horseshoe bat, Rhinolophus ferrumequinum (Schreber, 1774) (Rhinolophidae), contained coccidian oocysts. One species in the genus Eimeria was found in $P$. javanicus and is described here as new.

\section{MATERIALS AND METHODS}

Hosts were live-trapped in mist nets during June 1982. Fecal samples were collected from these bats and stored in $2 \%(\mathrm{v} / \mathrm{v})$ aqueous sulfuric acid $\left(\mathrm{H}_{2} \mathrm{SO}_{4}\right)$ solution. Methods for storing and processing fecal samples and for concentrating, measuring, and photographing oocysts have been described in detail (Duszynski et al., 1982; Stout and Duszynski, 1983). Measurements are in $\mu \mathrm{m}$, with size ranges in parentheses following the means. Oocysts were measured and photographed between 1983 and 1985, when they were between 235- and 1,098 days old. Skeletons, skins, and tissues for electrophoresis for all hosts (symbiotypes, see Frey et al., 1992) are permanently deposited in the Museum of Southwestern Biology (MSB), The University of New Mexico (UNM). Phototypes (=hapantotypes, see Bandoni and Duszynski, 1988) of sporulated oocysts of the new species have been deposited in the U.S. National Parasite Collection (USNPC), Beltsville, Maryland.

\section{DESCRIPTION}

\section{Eimeria redukeri $\mathbf{n}$. sp.}

(Figs. 1-4)

Description: Oocyst subspheroidal with wall $\sim 1$, composed of 2 layers (Fig. 1); outer layer mammillated (Figs. 2, 3), $2 / 3$ of total thickness, inner layer smooth; micropyle absent; oocyst residuum a single globe $2.0 \times 3.8$ (Figs. 1, 2); polar granule present; sporulated oocysts $(\mathrm{n}=$ $150), 20.3 \times 18.1(16-25 \times 14-21)$ with $\mathrm{L}: \mathrm{W}$ ratio $1.1(1.0-1.3)$; sporocysts $(n=150)$ ovoidal, slightly pointed at end with Stieda body, $10.6 \times 6.6(8-12 \times 5-8)$ with L:W ratio $1.6(1.2-1.9)$; Stieda body present (Figs. 1, 2), but sub- and parastieda bodies absent; sporocyst residuum of 1-3 refractile spheroids (Fig. 3); sporozoites with a posterior refractile body (Fig. 2).

\section{Taxonomic summary}

Type host: Pipistrellus javanicus (Gray, 1838).

Type locality: Japan, Honshu, Niigata, Shiunji, Shiun Golf Country Club.

Prevalence: Found in 1 of 4 (25\%) P. javanicus collected.

Received 15 July 1996; revised 5 November 1996; accepted 5 November 1996.
Site of infection: Unknown, oocysts collected directly from feces of the host.

Material deposited: Phototypes of sporulated oocysts in the USNPC, no. 86899. Host skin and skeleton, NK no. 6280 (female), T. L. Yates \#956, 26 June 1982, MSB no. 45547.

Etymology: The nomen trivale is given to honor the memory of Dr. David W. Reduker who, as a graduate student, helped collect the type host. David not only was my student, but he was a close friend and a budding young parasitologist with a bright future; he was an Assistant Professor of Pathology at Colorado State University, Ft. Collins, Colorado, before his untimely death on 25 October 1990.

\section{Remarks}

Eimeria redukeri is the second Eimeria species to be described from the genus Pipistrellus; the first was Eimeria macyi Wheat, 1975, collected from Pipistrellus subflavus from Alabama, U.S.A. (Wheat, 1975). It is the first species to be described in a bat from Japan. The new species is quite similar to $E$. macyi both in the mean size of its oocyst $(20.3 \times 18.1$ vs. $19.0 \times 17.6)$ and sporocyst $(10.6 \times 6.6$ vs. $11 \times 7)$ However, it differs from E. macyi in the number of obvious oocyst wall layers ( 2 vs. 1$)$, by the presence of a small oocyst residuum, and by lacking a substieda body, which is present in the sporocysts of $E$. macyi. Oocysts of both $E$. redukeri and $E$. macyi have a rough outer wall that presents a striated appearance in optical cross section.

\section{Eimeria sp.}

Eimerian oocysts were observed in 1 of $3 R$. ferrumequinum from Japan (Table I). The oocysts were subspheroid, $23.4 \times 19.2(19.5-26$ $\times$ 17-22.5), rough walled, with a polar granule and oocyst residuum clearly present; sporocysts were lemon-shaped with a Stieda body present. However, only 2 of 25 (8\%) oocysts were sporulated. Therefore, given the guidelines set forth by Duszynski and Wilber (1997), it is unrealistic to describe this Eimeria as a new species based only on the structure of 2 sporulated oocysts. There is only 1 other mention of coccidian oocysts being recovered from $R$. ferrumequinum. Labbé (1893) reported 3 types of oocysts in $R$. ferrumequinum in France: ovoid $20 \times 14$, spheroid 15 in diameter, and piriform 6-7 wide, with a truncated micropyle; no further descriptions were given and he named the organism Coccidium viride, a name later emended to Eimeria viridis by Reichenow (1921). Lavier (1924) and Pellérdy (1974) opined that Labbé was dealing with more than 1 species and relegated $E$. viridis to a nomen nudum; however, species inquirenda, a doubtfully identified species needing further investigation (Ride et al., 1985: 264), is a more technically correct designation.

\section{DISCUSSION}

To date, 15 eimerian species have been described from bats, including the new species described here. This seems a very small number given that bats comprise the 2nd most diverse order of mammals, with about 900 species (Nowak, 1994). Either coccidia simply have not been looked for in sufficient numbers (e.g., $<1,000$ individual bats ever have been examined for 

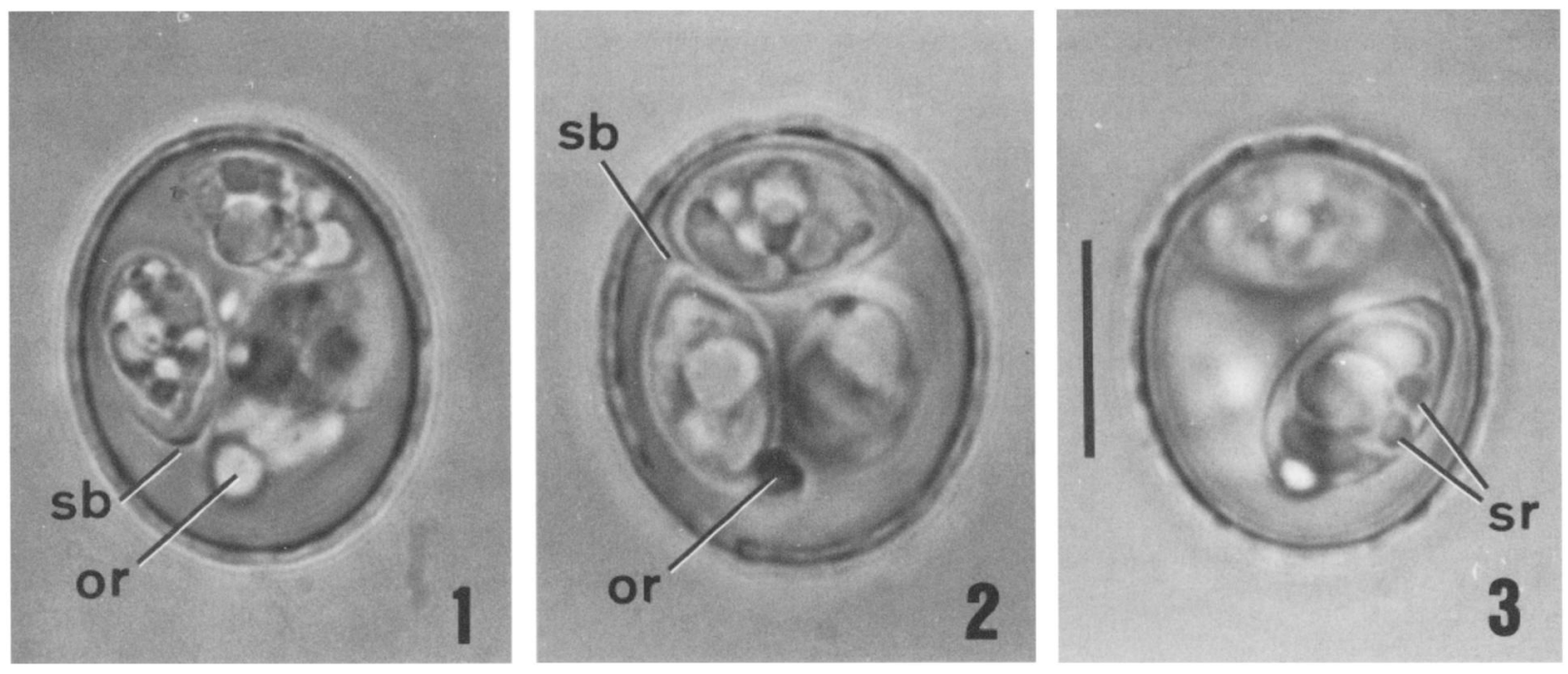

FIGURES 1-3. Photomicrographs of sporulated oocysts of Eimeria redukeri n. sp. recovered from the feces of Pipistrellus javanicus captured on the island of Honshu, Japan. Scale bar $=10 \mu \mathrm{m}$. Abbreviations: or, oocyst residuum; sb, Stieda body; sr, sporocyst residuum.

coccidian oocysts), or the overall prevalence of coccidian species in bats is just lower than in other mammals (e.g., rodents), for some unknown reason(s). These are questions that cannot be answered given the paucity of our knowledge about the parasites of this important, diverse, specious, and abundant group of mammals. In this small survey, only 2 bats ( $P$. javanicus and $R$. ferrumequinum) were infected singly with a different roughwalled eimerian species. Duszynski (1986) hypothesized that the sparseness of species of coccidia in some groups of small

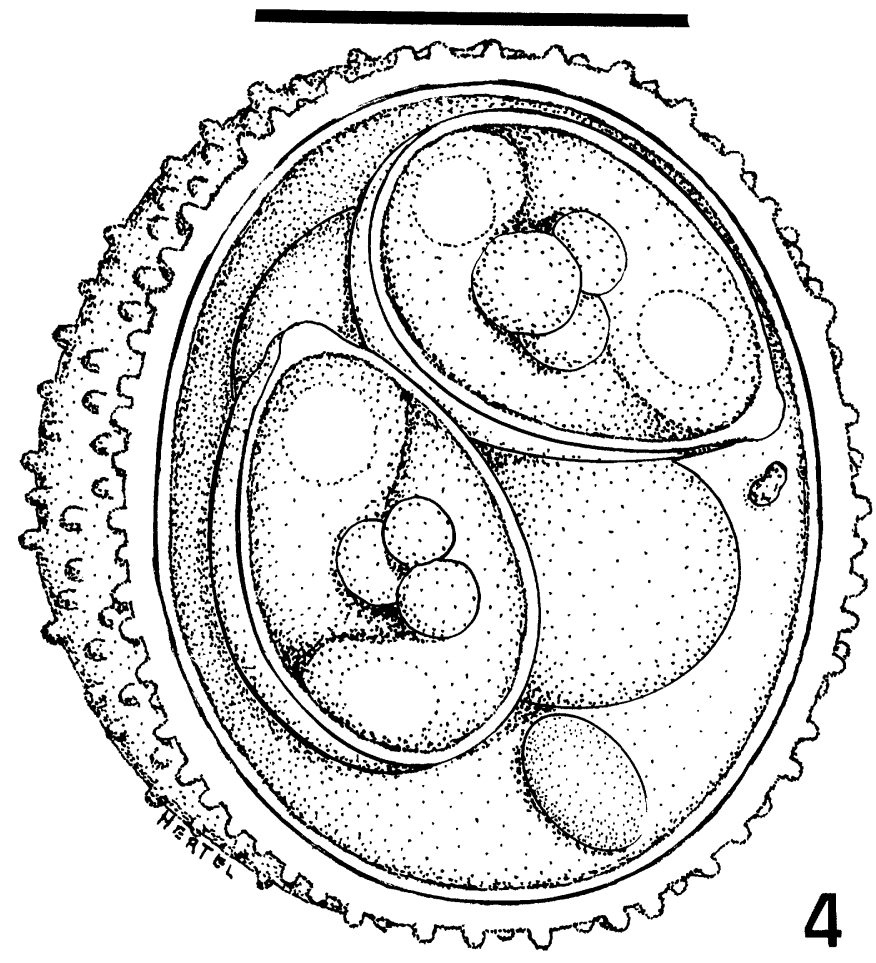

FIGURE 4. Composite line drawing of sporulated oocyst of Eimeria redukeri found in the feces of Pipistrellus javanicus. Scale bar $=10$ $\mu \mathrm{m}$. mammals, (e.g., bats), most likely reflects environmental (e.g., roosting sites), and host genetic factors (e.g., behavior). Duszynski et al. (1988) proposed that the feeding habits of bats may contribute to the low rate of infection in bat populations, although those authors found that insectivorous bats were no more heavily infected with coccidia than were fruit-eating bats. A study that critically examined a combination of these factors, for example, roosting habits, social interactions (solitary, gregarious), parasite load, host genetic relatedness, and so on, could add to our understanding of the prevalence of infection of different bat species by coccidia.

When feces are examined for coccidian oocysts, the possi-

TABLE I. Six species of bats representing 2 families taken from 5 collection localities in Japan and examined for coccidian oocysts.

\begin{tabular}{llc}
\hline Family/host species & Island, prefecture, locality & $\begin{array}{c}\text { No. hosts } \\
\text { infected/ } \\
\text { no. } \\
\text { examined } \\
(\%)\end{array}$ \\
\hline $\begin{array}{l}\text { Rhinolophidae } \\
\text { Rhinolophus } \\
\text { cornutus }\end{array}$ & Honshu, Hiroshima, Omi-no & \\
Rhinolophus & Iwaya Cave & $0 / 4$ \\
ferrumequinum & Tsushima, Nagasaki, Mine & $0 / 1$ \\
& Honshu, Hiroshima, Omi-no & \\
Vespertilionidae & Iwaya Cave & $1 / 1$ \\
Myotis macrodactylus & Tsushima, Nagasaki, Mine & $0 / 2$ \\
& Honshu, Hiroshima, Omi-no & \\
Pipistrellus javanicus & Iwaya Cave & $0 / 4$ \\
Plecotus auritus & Honshu, Nigata, Shiun Golf & $0 / 17$ \\
Vespertilio superans & Country Club & $1 / 4$ \\
& Honshu, Negano, Haramura & $0 / 1$ \\
& Honshu, Hiroshima, Omi-no & \\
2 Families, 6 species & Iwaya Cave & $0 / 22$ \\
\hline & 2 islands, 5 localities & $2 / 56(4)$ \\
\hline
\end{tabular}


bility always exists that when oocysts are found, they may be from another host (prey) that had been eaten by the host (predator, scavenger) being examined. Usually, however, such oocysts are distorted and found in small numbers. In the positive sample from $P$. javanicus, there were thousands of oocysts and the diet of this bat consists only of small insects caught in flight (Nowak, 1994). Thus, we have some confidence that $E$. redukeri is a bona fide parasite of $P$. javanicus and not a spurious infection. On the other hand, although $R$. ferrumequinum also is an aerial insectivore, it is known to feed on the ground and to include spiders in its diet (Nowak, 1994); thus, it is possible that the few oocysts we found in its feces may be a contaminant from another host animal.

Duszynski and Barkley (1985) first hypothesized a diphyletic origin for Eimeria spp. infecting bats. They proposed that Eimeria spp. from New World bats have thick mammilated oocyst walls and that those from Old World bats have smooth oocyst walls. At the time, this was supported by descriptions of eimerian species from New World bats (E. macyi, Eimeria tomopea, Eimeria eumopos) that have thick mammillated walls, and descriptions of 6 eimerian species from Old World bats (Eimeria dukei, Eimeria levinei, Eimeria nyctali, Eimeria vajsovi, Eimeria vespertilii, Eimeria zakirica) that have thin smooth walls (Levine and Ivens, 1981). However, both P. javanicus and $R$. ferrumequinum, Old World bats from Japan, were infected with different rough-walled Eimeria, which does not support the hypothesis for a diphyletic origin. Thus, oocyst wall texture may not be an appropriate structural feature for examining phylogenetic origins.

Finally, I should clarify the method of oocyst preservation used in this study, which contradicts the recent advice we gave in our guidelines for species descriptions (Duszynski and Wilber, 1997). In the late 1970s, we were trying to become more environmentally conscientious and had been searching for a solution in which to keep oocysts that did not contain heavy metals. We noted that some workers at the time (Smith and Frenkel, 1977) were using $2 \%$ aqueous (v/v) $\mathrm{H}_{2} \mathrm{SO}_{4}$ to preserve coccidian oocysts from the feces of cats experimentally infected with Besnoitia darlingi, without reported ill effect on the oocysts. Thus, in our work in Japan, all feces from bats and other mammalian hosts (Wash et al., 1985) were collected and stored in $2 \% \mathrm{H}_{2} \mathrm{SO}_{4}$. Unfortunately, this was a mistake because $2 \%$ $\mathrm{H}_{2} \mathrm{SO}_{4}$, unlike $2 \%$ aqueous (w/v) potassium dichromate $\left(\mathrm{K}_{2} \mathrm{Cr}_{2} \mathrm{O}_{7}\right)$, seemed especially detrimental to the structural integrity of many of the oocysts stored in it and to the ability of the oocysts to sporulate at the higher rates we have learned to expect when they are stored in the standard dichromate solution.

\section{ACKNOWLEDGMENTS}

This study was supported, in part, by NSF grant DEB8004685 to Dr. T. L. Yates, Department of Biology, UNM, and, in part, by an NSF-PEET grant (DEB-9521687) to me. I am also indebted to Drs. S. L. George, D. W. Moore, and D. W. Reduker who, as graduate students on this field trip, helped collect and process all hosts. I am indebted to my friend and colleague, Dr. Terry Yates, whose NSF grant facilitated this field trip and to Dr. Takashi Setoguchi, his colleagues, and the students of the Primate Research Institute of Kyoto University, for logistical support while in Japan. Mr. D. Scott read earlier versions of this manuscript and gave me many helpful suggestions; he also did all of the darkroom work. Finally, I want to thank two other friends and contempories of David Reduker: L. Hertel, for the line drawing, and P. Ford, for technical assistance in handling the samples.

\section{LITERATURE CITED}

Bandoni, S. M., AND D. W. Duszynski. 1988. A plea for improved presentation of type material for coccidia. Journal of Parasitology 74: 519-523.

DUSZYNSKI, D. W. 1986. Host specificity in the coccidia of small mammals: Fact or fiction? In Advances in protozoological research, $\mathbf{M}$. Bereczky (ed.). Symposia Biologica Hungarica, Vol. 33. Akademiai Kiado, Budapest, Hungary, p. 325-337.

- AND L. J. BARKLEY. 1985. Eimeria from bats of the World: A new species in Tomopeas ravus from Peru. Journal of Parasitology 71: 204-208.

- , G. Eastham, and T. L. Yates. 1982. Eimeria from jumping mice (Zapus spp.): A new species and genetic and geographic features of $Z$. hudsonicus luteus. Journal of Parasitology 68: 11461148.

, D. W. Reduker, AND B. B. PARKer. 1988. Eimeria from bats of the World. II. A new species in Tadarida femorasacca from Sonora, Mexico. Journal of Parasitology 74: 317-321.

, AND P. G. WILBER. 1997. A guideline for the preparation of species descriptions in the Eimeriidae. Journal of Parasitology (in press).

Frey, J. K., T. L. Yates, D. W. Duszynski, W. L. Gannon, and S. L. GARDNER. 1992. Designation and curatorial management of type host specimens (symbiotypes) for new parasite species. Journal of Parasitology 82: 930-932.

LABBÉ, A. 1893. Sur les coccidies des oiseaux. Comptes Rendus Hebdomadaires des Séances de l'Académie des Sciences, Paris 116: 1300-1303.

LAVIER, G. 1924. Eimeria hessei n. sp., coccidie intestinale de Rhinolophus hipposideros. Annales de Parasitologie Humaine et Compareé, Paris 2: 335-339.

LeVine, N. D., AND V. Ivens. 1981. The coccidian parasites (Protozoa, Apicomplexa) of bats. In Parasitological topics: A presentational volume to P. C. C. Garnham, F.R.S., on the occasion of his 80th birthday, E. U. Canning (ed.). Society of Protozoologists, Special Publication No. 1, Allen Press, Inc., Lawrence, Kansas, p. 170176.

NowaK, R. M. 1994. Walker's bats of the world. The Johns Hopkins Press, Ltd., London, U.K., 287 p.

Pellérdy, L. P. 1974. Coccidia and coccidiosis, 2nd ed. Akademiai Kiado, Budapest, Hungary, 959 p.

Reichenow, E. 1921. Handbuch der Pathogenen Protozoen 8: 11361277.

Ride, W. D. L., C. W. Sabrosky, G. Bernardi, and R. V. Melville (eds.). 1985. International code of zoological nomenclature, 3rd ed. H. Charlesworth and Co. Ltd., Huddersfield, U.K., 338 p.

Smith, D. D., AND J. K. Frenkel. 1977. Besnoitia darlingi (Protozoa: Toxoplasmatinae): Cyclic transmission by cats. Journal of Parasitology 63: 1066-1071.

Stout, C. A., AND D. W. DuszYnSKI. 1983. Coccidia from kangaroo rats (Dipodomys spp.) in the western United States, Baja California, and northern New Mexico with descriptions of Eimeria merriami sp. n. and Isospora sp. Journal of Parasitology 69: 209-214.

Wash, C. D., D. W. Duszynski, AND T. L. YATES. 1985. Eimerians from different karyotypes of the Japanese wood mouse (Apodemus spp.), with descriptions of two new species and a redescription of Eimeria montgomeryae Lewis and Ball, 1983. Journal of Parasitology 71: 808-814.

WheAt, B. E. 1975. Eimeria macyi sp. n. (Protozoa: Eimeriidae) from the eastern pipistrelle, Pipistrellus subflavus, from Alabama. Journal of Parasitology 61: 920-922. 